\title{
Literasi Media Digital di Lingkungan Ibu-Ibu Rumah Tangga di Yogyakarta
}

\author{
Dewi Novianti dan Siti Fatonah \\ Prodi Ilmu Komunikasi UPN "Veteran" Yogayakarta \\ Email: dewinovianti_upn@yahoo.co.id \\ Email: onacahya@yahoo.co.id
}

\begin{abstract}
This digital media literacy research took the subject of research of housewives in Banguntapan, Bantul. This study aims to give suggestions in developing media literacy model to the village of media literacy, especially for housewives in Banguntapan, Bantul. The method used is literature study, in-depth interview, observation, and FGD. Theories used are Digital Media Theory and Media Literacy. The results showed that most housewives in the village of Babadan, Banguntapan, Bantul have not known what digital media literacy. They are used to using gadgets or smartphones. They are active in dasa wisma or PKK and other village activities in their environment. After the FGDs were held, socialization and training of digital media literacy, these mothers became agents of digital media literacy change. These housewives socialize and disseminate digital media literacy both in their family environment, as well as in the institutions or organizations in which they are members of the board or members therein. They managed to invite the environment to intelligently consume media, especially digital media. The village of Babadan where housewives live can be used as a pilot village of digital media literacy.
\end{abstract}

Keywords: media literacy, media literacy village, Digital media theory

\begin{abstract}
Abstrak
Penelitian literasi media digital ini mengambil subyek ibu-ibu rumah tangga di Banguntapan, Bantul.. Penelitian ini bertujuan memberikan usulan dalam mengembangkan model literasi media menuju desa melek media bagi Ibu-Ibu Rumah Tangga di lingkungan Banguntapan, Bantul. Metode yang digunakan adalah studi pustaka, wawancara mendalam, observasi, dan FGD. Teori yang digunakan adalah Teori Media Digital dan Literasi Media. Hasil penelitian menunjukkan bahwa sebagian besar ibu-ibu rumah tangga di Desa Babadan, Banguntapan, Bantul belum mengenal cara menggunakan media digital cerdas. Mereka sudah biasa menggunakan gadget atau smartphone. Mereka aktif di dasa wisma atau PKK serta aktivitas desa lainnya di lingkungannya. Setelah diadakan FGD, sosialisasi serta pelatihan literasi media digital, ibu-ibu ini menjadi agen-agen perubahan literasi media digital. Ibu-ibu rumah tangga tersebut menyosialisasikan dan mendiseminasikan literasi media digital baik di lingkungan keluarganya, maupun di lembaga-lembaga atau organisasi-organisasi di mana mereka menjadi pengurus atau anggota di dalamnya. Mereka berhasil mengajak lingkungannya untuk cerdas mengonsumsi media, khususnya media digital. Desa Babadan di mana ibu-ibu rumah tangga tersebut tinggal bisa dijadikan desa percontohan melek media digital.
\end{abstract}

Kata kunci : literasi media, desa melek media, Teori media Digital 


\section{Pendahuluan}

Media sebagai sumber informasi bagi khalayak ternyata tidak lagi sepenuhnya dapat dijadikan sumber informasi yang akurat. Media yang sejatinya merupakan wadah pengawasan lingkungan (Surveillance), korelasi antara bagian dalam masyarakat (linkage), sosialisasi atau pewarisan nilai-nilai (transmission of values), serta sebagai hiburan (entertainment), pada kenyataannya jauh panggang dari api.

Khususnya televisi, diyakini banyak menghadirkan program siaran yang tidak mendidik. Di televisi lebih mengedepankan program-program hiburan yang kurang memperhatikan etika dan norma masyarakat. Mereka tidak peduli terhadap dampak negatif program siaran yang dikedepankan tersebut, misalnya eksploitasi terhadap perempuan, anak, kemiskinan, humor yang rendah, gaya hidup bebas dan sebagainya. Yang lebih mendominasi adalah dampak narcotizing disfunction (fungsi membius).

Penelitian ini merupakan lanjutan dari penelitian sebelumnya. Berdasarkan hasil temuan pada penelitian sebelumnya, di Desa Babadan Kecamatan Banguntapan Bantul, hasil pemetaan kemampuan media narasumber ternyata beragam. Secara umum ibu-ibu rumah tangga tersebut merupakan aktifis PKK dan Pengajian. Sebagian besar adalah wanita pekerja. Mereka memanfaatkan media pada waktu sore dan malam hari setelah pulang bekerja. Media favorit adalah TV.

Untuk media cetak seperti koran, majalah atau tabloid sangat jarang dibaca. Waktu mengonsumsi media khususnya TV adalah pagi sebelum berangkat kerja dan sore sampai malam hari setelah pulang bekerja. Pendampingan menonton televisi pada anak sudah dilakukan, akan tetapi acara yang ditonton masih bersifat hiburan. Durasi menonton juga masih tergolong tinggi yakni sekitar lima jam sehari. Bahkan ada yang menggunakan televisi sebagai media untuk menghantar tidur keluarga.

Setelah memetakan media ibu-ibu rumah tangga tersebut, peneliti menemukan model literasi media yang tepat untuk diterapkan bagi ibu-ibu rumah tangga. Model literasi diawali dengan sosialisasi media. Sosialiasi ini sangat perlu diterapkan pada ibu-ibu rumah tangga. Sosialisasi media bisa dibagi ke dalam dua bentuk; pertama, pelatihan secara berkala literasi media khusus untuk media konvensional (TV, radio Koran, majalah, tabloid, film). Kedua, pelatihan khusus literasi media baru (internet, media sosial) situs-situs yang dianggap penting untuk diketahui oleh ibu-ibu. Ini diberikan agar tidak tergelincir oleh isu-isu yang ada. Cara mongonsumsi media dengan cerdas bagi ibu-ibu rumah tangga perlu dibimbing dan diarahkan. Solusinya pembatasan durasi mengonsumsi media terutama konten hiburan, pemilihan program yang tepat bagi keluarga, pendampingan terhadap anak, dan menciptakan budaya membaca bagi keluarga.

Dari paparan di atas penelitian literasi media pada ibu-ibu rumah tangga, memperlihatkan bahwa setiap harinya ibu-ibu tersebut mengonsumsi media untuk hiburan dan mendapatkan informasi. Temuan tahun pertama menjadi landasan pengembangan model litarasi media pada tahun kedua dengan memfokuskan pada media digital seperti media sosial ; whatshap, Line, Instagram, facebook, tweetter. Berbagai kalangan telah menggunakannya, baik tua maupun muda. Sementara Ibu-Ibu rumah tangga yang menjadi subyek penelitian ini masih gagap teknologi.

Konten-konten dari media baru ini tidak bisa dianggap hanya sebagai hiburan saja, akan tetapi ada banyak konten yang meresahkan seperti seksualitas, kekerasan, eksploitasi tubuh wanita, fenomena bully, kriminalitas, berita hoax, dan informasi-informasi yang tidak jelas sumber dan kebenarannya. Peneliti melakukan suatu langkah solutif berupa usulan kebijakan litersi media kepada pemerintah, agar gerakan literasi media segera terwujud. Implementasi model ini memerlukan sinergi beberapa pihak terkait seperti departemen Komunikasi dan Informasi, Komisi Penyiaran Indonesia Daerah (KPID), pakar media, dan Non Goverment Organization 
(NGO). Sinergi harmonis diharapkan menghasilkan warga negara yang 'bijak dalam bermedia', 'cerdas dalam berinteraksi dengan media', serta memiliki selfcontrol yang kuat. Diawali dari keluarga, dimana peran ibu sangat dominan, sehingga yang menjadi target utama dalam penelitian ini adalah para ibu. Pelatihan literasi media akan diberikan kepada para ibu rumah tangga di dua kecamatan. Muara akhir riset ini akan mewujudkan "Desa Melek Media".

Tujuan penelitian ini adalah pertama, sosialiasi model literasi media digital di lingkungan Ibu-Ibu Rumah Banguntapan Bantul, DI Yogyakarta. Kedua, memberikan pelatihan literasi media digital. Ketiga, menjadikan ibuibu yang telah dipilih menjadi agen-agen literasi media digital lingkungannya. Keempat, mewujudkan "Desa Melek Media" sebagai embrio lahirnya generasi terpelajar berakhlak mulia yang 'bijak dalam bermedia', 'cerdas dalam berinteraksi dengan media', serta memiliki selfcontrol yang kuat. Kelima, membuat Model Literasi Media Digital Bagi Ibu-Ibu Rumah Tangga.

Pemahaman media literacy atau melek media secara sederhana adalah bagaimana khalayak mampu memilih atau menyaring isi pesan yang disampaikan oleh media. Khalayak mampu membedakan mana yang dianggap penting atau baik dan mana yang dianggap buruk. Pada dataran ini khalayak sudah semakin cerdas, aktif dan kritis. Bahkan khalayak tidak begitu saja mempercayai pesan yang disampaikan oleh media. Untuk itulah dibutuhkan adanya media edukasi dalam konteks media literacy. Wirodono dalam Rejeki (2010:67) mengemukakan tiga kategori khalayak yang rentan terhadap pengaruh buruk media, yakni anak-anak, remaja, dan kaum ibu.

Pada anak-anak, pengaruh itu terutama terletak pada perkembangan otak, emosi, sosial, dan kemapuan kognitif. Intensitas akan memengaruhi persepsi dengan apa yang mereka tonton. Kekhawatiran tersebut misalnya dari pengaruh tayangan kekerasan pada anak-anak yang sering ditiru. Selain itu tayangan berbau seks dan mistis menjadi kekhawatiran para ibuibu. Pada remaja, tayangan sinetron dengan tema remaja cenderung mengeksploitasi kehidupan remaja dari satu sisi. Keadaan ini menyebabkan remaja tidak bisa mempelajari realitas yang sesungguhnya. Bagi ibu-ibu pengaruh buruk televisi lebih pada membangun perilaku konsumtif. Mereka merupakan sasarn potensial iklan. Komoditas ini dikemas dalam bentuk tayangan sinetron, infotainment, tayangan kuliner dan sebagainya (Wirodono dalam Rejeki, 2010:69).

Istilah literasi media baru sering disamakan dengan digital literacy atau literasi digital karena media baru dapat dikatakan identik dengan media digital, meskipun tidak selalu berarti Internet. Menurut Media Awareness Network (dengan memadukan rumusan dari National Broadband Plan Connecting Maerican Section 9.3, Digital Britain Media Literacy Working Group Section 3.16, dan Australia's Digital Economy: Future Directions, p. 44), definisi literasi digital yang sudah cukup dikenal adalah: Keterampilan dan pengetahuan yang diperlukan untuk menggunakan berbagai perangkat lunak aplikasi media digital, perangkat keras seperti komputer, telepon selular, dan teknologi internet; kemampuan untuk secara kritis memahami konten media digital dan aplikasinya; dan pengetahuan dan kapasitas untuk menciptakanisi media dengan teknologi digital.

Apabila diuraikan lebih jauh di dalam definisi tersebut terkandung tiga kata kerja yang merupakan karakteristik dari literasi digital, yaitu: use - understand - create. Artinya, literasi media mencakup kemampuan untuk menggunakan, memahami, dan memproduksi media digital. Penjelasan lebih jauh mengenai ketiga komptensi tersebut adalah.:

1. Menggunakan - merupakan keahlian teknis yang dibutuhkan untuk terlibat dengan komputer dan internet. Keahlian ini membentuk dasar untuk pengembangan literasi digital yang lebih dalam. Keterampilan teknis yang 
penting meliputi kemampuan untuk menggunakan program komputer seperti pengolah kata, web browser, e-mail, dan alat komunikasi lainnya. Untuk mengembangkan keterampilan ini, warga harus memiliki akses dan dapat memanfaatkan peralatan dan sumber daya dengan nyaman seperti layanan broadband, komputer, perangkat lunak, mesin pencarian Internet, dan database online.

2. Mengerti - adalah kemampuan untuk memahami, mengontekstualisasikan, dan mengevaluasi media digital secara kritis. Individu harus menyadari pentingnya melakukan evaluasi secara kritis dalam memahamibagaimanakonten danaplikasi media digital dapat mencerminkan, membentuk, meningkatkan atau memanipulasi persepsi, keyakinan, dan perasaan kita tentang dunia di sekitar kita. Sebuah pemahaman kritis tentang media digital memungkinkan individu untuk menuai keuntungan - dan mengurangi resiko - serta berpartisipasi penuh dalam masyarakat digital. Keterampilan ini mencakup juga pengembangan keterampilan manajemen informasi dan penghargaan terhadap hak dan tanggung jawab terhaap kekayaan intelektual. Individu perlu tahu bagaimana menemukan, mengevaluasi, dan menggunakan informasi secara efektif untuk berkomunikasi, berkolaborasi dan memecahkan masalah dalam kehidupan pribadi dan profesional.

3. Memproduksi - adalah kemampuan untukmembuatkonten dan berkomunikasi secara efektif menggunakan berbagai alat media digital. Produksi konten dengan menggunakan media digital tidak sekedar kemampuan untuk menggunakan pengolah kata atau menulis email: namun termasuk di dalamnya kemampuan berkomunikasi dalam berbagai konteks khalayak; untuk membuat konten dan berkomunikasi dengan menggunakan berbagai format seperti gambar, video, dan suara; dan untuk secara efektif dan bertanggungjawab memanfaatkan fasilitas "Web 2.0 user-generated content" seperti blog dan forum diskusi, berbagai video dan foto, game sosial, dan bentuk lain dari media sosial. Kemampuan untuk membuat dengan media digital memastikan bahwa seseorang tidak hanya konsumen pasif tetapi secara aktif berkontribusi dalam masyarakat digital (Sumber: unduh Guntarto http://www. media-awareness.ca/english/corporatel media_kit/digital_literacy_paper_pdf/ digitalliteracypaper_part1.pdf tanggal unduh tgl 08 Juni 2017).

Model literasi digital yang dikembangkan dari literasi media konvensional adalah seperti dalam gambar di bawah ini.

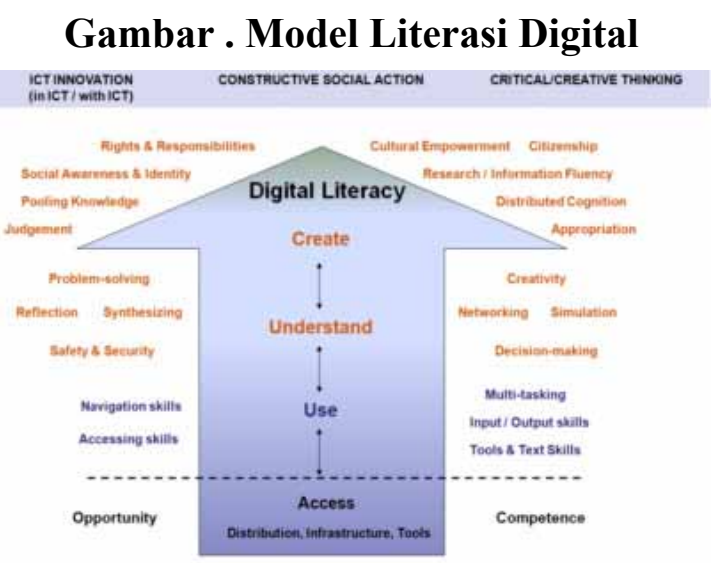

Sumber: Media Awareness Network

Skema di atas memperlihatkan kompetensi aktif seseorang yang memiliki kemampuan literasi digital, yang terdiri atas menggunakan, memahami, dan memproduksi konten. Di bawah payung literasi digital terdapat sejumlah keterampilan yang saling berhubungan mulai dari kesadaran dasar dan pelatihan untuk mendorong warga yang paham dan percaya diri hingga memiliki kemampuan literasi, kritis, dan kreatif yang canggih sebagai hasil akhirnya. Sedangkan keterampilan literasi media yang dirumuskan oleh Henry Jenkins tersebut mencakup (Jenkins, 
2007):

1. Bermain-kapasitas untuk bereksperimen dengan lingkungan seseorang sebagai bentuk pemecahan masalah

2. Kinerja-kemampuan untuk mengadopsi identitas alternatif untuk tujuan improvisasi dan penemuan

3. Simulasi - kemampuan untuk menafsirkan dan membangun model dinamis dari proses dunia nyata

4. Kecocokan - kemampuan untuk memaknai informasi dan mengemas ulang konten media

5. Multitasking - kemampuan untuk memindai lingkungan dan seringkali berpindah fokus perhatian

6. Kognisi Terdistribusi - kemampuan untuk berinteraksi secara bermakna dengan peralatan yang dapat memperluas kapasitas mental

7. Kecerdasan Kolektif - kemampuan pengetahuan kolam renang dan membandingkan catatan dengan lain menuju tujuan bersama Penghakiman - kemampuan untuk mengevaluasi keandalan dan kredibilitas informasi yang berbeda sumber

8. Penilaian - kemampuan untuk mengevaluasi sumber informasi

9. Navigasi transmedia - kemampuan untuk mengikuti alur cerita dan informasi dalam berbagai modalitas

10. Jaringan - kemampuan untuk mencari, mensintesis, menyebarkan informasi

11. Negosiasi-kemampuan untuk mendekati komunitas yang beragam, memahami berbagai perspektif, dan memegang serta mengikuti norma-norma

Jenkins lebih menekankan budaya partisipatif dan bukan pada interaktivitas karena interaktivitas adalah properti dari teknologi, sementara partisipasi adalah properti budaya. Budaya partisipatif muncul sebagai budaya yang menyerap dan merespon ledakan teknologi media baru yang memungkinkan bagi konsumen pada umumnya untuk menyimpan, memanfaatkan, dan menyebarluaskan konten media dengan cara-cara baru yang efektif.

\section{Metode Penelitian}

Penelitian ini adalah penelitian kualitatif yang sering diistilahkan dengan penelitian naturalistik dalam bidang Sosiologi, penelitian etnografi dalambidangAntropologi dan penelitian studi kasus dalam bidang Psikologi (Sutopo, 2001 : 5-6). Neuman (2000 : 65) menyebutkan adanya tiga perspektif dalam Ilmu Sosial yang akan membedakan dalam teknik penelitian, yaitu : Positivist, interpretive dan critical. Pendekatan kuantitatif berada di bawah perspektif positivist, sedangkan pendekatan kualitatif berada di bawah perspektif interpretive/constructivis dan critical (Neuman, $2000: 65$ )

Obyek dalam penelitian ini adalah memetakan kemampuan literasi media dari Ibu-Ibu di Lingkungan Banguntapan Bantul DI Yogyakarta. Selanjutnya mengembangkan model yang tepat untuk dapat diimpletasikan serta dijadikan kebijakan untuk mencerdaskan Ibu-Ibu rumah tangga Banguntapan Bantul DI Yogyakarta dalam berinteraksi dengan media digital.

Sumber data terdiri dari data primer dan data sekunder. Data primer berupa wawancara mendalam dengan instrumen Interview guide, observasi, dan FGD. Sedangkan data sekunder berupa analisis isi dan studi pustaka. Teknik analisis yang akan digunakan adalah analisis antar kasus (cross-site analysis). Pada tiap kasusnya akan dilakukan dengan menggunakan model analisis interaktif. Dalam model analisis ini, tiga komponen analisisnya yaitu : reduksi data, sajian data dan penarikan kesimpulan atas verifikasinya, dilakukan dalam bentuk interaktif dengan proses pengumpulan data sebagai suatu proses siklus (Sutopo, 2002). Setiap kasus dilakukan analisis interaktif. Dalam kegiatan reduksi data, dilakukan seleksi data, pemfokusan, penyederhanaan, dan abstraksi data dari fieldnote (catatan lapangan). Proses ini berlangsung terus sepanjang pelaksanaan penelitian. Dalam 
kegiatan penyajian data, dilakukan pengolahan data dan dituliskan dalam deskripsi dalam bentuk narasi yang disusun secara logis dan sistematis yang memungkinkan dapat ditarik adanya simpulan-simpulan penelitian. Dalam kegiatan penarikan simpulan dan verifikasi, dilakukan pengulangan, pengujian, penelusuran, pencocokan data sehingga dihasilkan data yang mempunyai validitas tinggi. Validitas dalam penelitian ini menggunakan validitas sumber.

\section{Hasil Penelitian dan Pembahasan}

Media digital bukanlah barang baru bagi masyarakat Indonesia. Penggunannya tidak hanya dari kalangan atas saja, akan tetapi masyarakat dari lapisan bawah. Kemudahan dalam mengakses berbagai informasi ada pada media digital ini. Tidak hanya menawarkan informasi, media digital juga memberikan peluang usaha, hiburan dan pendidikan. Namun di samping manfaat di atas, media digital juga rentan akan kejahatan, penipuan, dan manipulasi data.

Media baru yang marak digunakan saat ini mengalahkan media konvensional menimbulkan dampak bagi penggunanya, terutama bagi anak-anak. Dalam buku The Handbook of Comunication Science, dibahas mengenai Computer Mediated Communication, yang mengemukakan 6 hal yang akan selalu terkait dan menyertai komunikasi sosial melalui internet (Berger, Roloff, Ewoldsen, 2010:494);

1) Berkurangnya komunikasi tatap muka dan cenderung berkurangnya ekspresi non verbal yang memang sudah menjadi ciri dalam interaksi melalui tulisan/text

2) Berhubungan dengan orang-orang yang tidak mengetahui topik atau dengan orang-orang yang memang menjadi bagian dari topik pembahasan

3) Bagaimana penggambaran diri sendiri dan orang lain melalui anonimitas yang absolut, pseudonymity, identifikasi nominal atau usaha untuk mengautentifikasi kualifikasi orang lain

4) Waktu berbalas pesan yang tidak sinkron

5) Khalayak potensial yang dapat dijangkau jauh lebih besar dibandingkan dengan jumlah individu dalam komunikasi tradisional

6) Mampu menjawab pesan secara 'bersembunyi' tanpa mengacaukan pesan.

\section{Literasi Media Digital bagi Ibu-Ibu Rumah Tangga Yogyakarta}

Berdasarkan hasil penelitian melaluifocus group discussion (FGD) dan wawancara, semua narasumber merupakan aktivis organisasi yakni Pendidikan Kesejahteraan Keluarga (PKK), Dasa Wisma, Aisyiyah, dan kelompok pengajian. Ibu Atikah misalnya beliau menjadi direktur Bank Sampah, pendidik pada Pendidikan Anak Usia Dini (PAUD), Posyandu, dan juga di bagian Pertanian. Ibu Dewi aktif di Dasawisma, ketua PKK, kader Lasis, Kader Batita, Bank Sampah, sekretaris AISYAH cabang ranting, Koperasi, dan lain-lain. Bu Suwari sebagai Pengurus PKK dan juga ketua USEB. Bu Subariyah Pengelola USEB, Pengurus PKK, Bendahara PKK RW, KOJA 2, Kader KB dan anggota Forum Lansia. Ibu Tri hampir sama dengan ibu-ibu yang lain, semua adalah kader.

Ibu-Ibu yang menjadi subyek penelitian ini diberi sosialisasi dan pelatihan literasi media digital. Peneliti mengundang Non Goverment Organization (NGO) literasi media yakni Masyarakat Peduli Media (MPM). Sebelum melakukan sosialisasi peneliti memetakan pengetahuan subyek penelitian tentang media digital dan penggunaannya. Semua yang menjadi subyek penelitian ini telah memiliki gadget atau smartphone. Namun penggunaanya hanya sebatas SMS dan WA. Email dan Facebook sehingga masih sangat kurang. Hal ini disebabkan mereka tidak tahu bagaimana menggunakan media digital tersebut.

Anak-anak mereka lebih canggih dalam menggunakan media digital ini seperti WA, FB, Tweeter, instagram, Youtube dan lain-lain. Sayangnya ibu-ibu ini tidak tahu bagaimana cara melacak historis substansi media tersebut 
sehingga konten-konten apa saja yang sudah dikonsumsi oleh anak-anak mereka, tidak diketahui. Hal yang dikhawatirkan adalah konten media yang menyesatkan seperti; beritaberita hoax, pornografi, sexualitas, kriminalitas, eksploitasi tubuh perempuan, iklan-iklan yang menawarkan perilaku konsumtif, pembullyan, kata-kata kasar dan sebagainya.

Peserta pelatihan literasi media digital ini sangat antusias. Banyak informasi yang sebelumnya mereka belum mengetahuinya, akhirnya setelah mengikuti pelatihan mereka menjadi tahu. Seperti bagaimana cara melacak historis konten media serta mereka menjadi bisa membedakan mana berita hoax dan mana yang benar. Mereka juga menjadi tahu bahwa mengupload pesan itu harus berhati-hati terutama di media umum seperti FB, instagram, tweeter, karena pesan tersebut akan dikonsumsi oleh orang banyak, heterogen, dan tersebar dengan cepat. Kalau yang di upload hal-hal yang bersifat pribadi, maka ini akan menjadi aib yang sulit untuk diklarifikasi.

Menurut Feri (salah seorang NGO MPM) bahwa "ada dua kunci dari kata literasi media, pertama literasi yang kedua media. Pertama, sekilas literasi media adalah melek media. Sebenarnya literasi itu bisa menjadi sangat luas. Literasiitu sebenarnya secara sederhana dikatakan kecakapan. Dengan demikian, yang dikatakan literasi itu ketika seseorang bisa menggunakan alatnya. Kedua adalah kemampuan memilah dan memilih. Setelah seseorang bisa menggunakan, kemudian bisa memilah dan memilih. Misalnya, kalau dalam media berarti kita bisa memilih acara mana yang mau kita tonton dan kita sukai, dan tidak kita sukai. Ketiga, adalah kemampuan untuk memproduksi sendiri.

Secara umum masyarakat baru sampai pada taraf kedua yakni memilih dan memilah tayangan atau konten media, atau isi media. Tingkatan ketiga, memproduksi sebenarnya dapat digunakan untuk apa? Bisa menggunakan media, bisa memilah dan memilih, memproduksi, sebenarnya literasi media itu menginstruksikan bahwa kecakapan tersebut digunakan untuk aspek kemanfaatan (FGD tgl 18 April 2017).

Ketika ditanyakan apakah ibu-ibu sudah bisamemproduksiinformasimelaluismartphone? Semuanya menyatakan bisa. Konten-konten yang diproduksi seperti mempromosikan produk untuk dijual, menyampaikan berita lelayu, menyampaikan informasi apa saja kepada keluarga, kerabat, dan teman. Informasi bisa disampaikan menggunakan whatshap, Line, tweetter, dan facebook. Di samping itu informasi bisa diperoleh melalui berita on line seperti Kompas.com, viva news.com, berita satu.com, dan masih banyak lagi. Hampir semua media konvensional berkonvergensi dengan media digital on line.

Namun sayangnya peliputan konten media tersebut, wartawan terkadang hanya mengutip berita dari media lain seperti Kantor Berita Antara, dari British Broadcasting (BBC), Cable News Network (CNN), Voice Of America (VOA), dan sebagainya kemudian dikonstruksi kembali sehingga muncul berita yang sebenarnya bukan hasil liputan sang wartawan itu sendiri. Hal inilah yang menyebabkan terjadi berita hoax.

Pertanyaan lainnya yang ditujukan kepada ibu-ibu Rumah Tangga tersebut, dari media internet konten apa yang sering dibuka? Ibu-ibu menjawab tampilan. Ibu Anik mengatakan bahwa kalau membuka facebook suka melihat tampilannya. Ketika ditanyakan apa yang menjadi patokan dalam memilih informasi media? Ibu-ibu menjawab "kemanfaatannya dan bisa dipertanggungjawabkan".

Tim NGO MPM lainnya Pambudi mengatakan "untuk media digital misalnya WA kita tidak akan bisa menolak, atau Facebook, kadang juga instagram, tiba-tiba nge-tag kita, sms tiba-tiba masuk informasi yang kita tidak mengenal pengirimnya. Ada beberapa cara untuk mengantisipasinya dengan memblokir nomor telpon tersebut. Kadang-kadang ada sms 'mama minta pulsa' itu dapat nomor kita darimana dia? Sekarang ada teknologinya bisa diacak, bisa pakai random. Tema lainnya yang sering menjadi berita HOAX adalah lowongan pekerjaan. Cara sederhana untuk mengetahui itu 
berita HOAX atau bukan biasanya yang pertama dilakukan adalah dengan bertanya di grup, bisa grup WA, LINE, FB. Kalau ahli Information and Technology (IT) bisa mendeteksi dari nomor HP yang digunakan" (hasil FGD tgl 18 April 2017). Ibu Ida peserta FGD menambahkan bahwa apakah berita tersebut termasuk hoax atau bukan bisa juga dengan melihat comment netizen. Pambudi menambahkan "untuk memilah dan memilih informasi bisa dengan melihat siapa audiensnya, resource-nya, dan produksinya. ( FGD, 18 April 2017)..

Dalam FGD ada banyak contoh kasus yang disampaikan oleh narasumber. Diantaranya kasus informasi lowongan pekerjaan untuk menjadi model yang pernah marak di Sleman melalui instagram. Banyak remaja putri tergiur, pertama yang diminta adalah foto wajah, dianggap kurang meyakinkan, kemudian diminta foto penuh setengah terbuka, agensi berdalih apakah badannya cocok atau tidak. Semuanya tergiur, padahal itu adalah ranah privacy atau aurat yang seharusnya tidak diumbar.

Intinya adalah semua anggota keluarga harus benar-benar diingatkan untuk bisa memilah dan memilih informasi secara berhati-hati, perlu cross check informasi. Termasuk pula dalam memposting informasi. Jangan semua informasi diposting, harus berpikir panjang, karena segala sesuatu yang sudah disampaikan melalui media tidak bisa dihapus. Berita yang sudah tersebar melalui media digital akan dengan mudah dicopy paste dan menjadi viral.

Mereka juga diingatkan bahwa karakter media itu beragam, seperti SMS digunakan untuk percakapan dua orang. Beda dengan WA, ada fasilitas untuk percakapan berdua saja, ada yang untuk grup. Facebook lebih luas lagi, bahkan cakupan wilayahnya bisa dunia, sehingga harus jauh lebih berhati-hati lagi dalam memposting informasi maupun foto-foto pribadi.

Khusus untuk Facebook (FB) harus ektra berhati-hati. Pambudi menjelaskan walaupun dari FB sendiri sudah membatasi bahwa yang boleh menggunakan FB adalah di atas usia 13 tahun.
Namun dalam prakateknya banyak anak-anak di bawah usia 13 tahun yang sudah menggunakan FB. Data pribadi yang diposting melalui FB bisa saja dibajak atau dipalsukan oleh hacker atau penjahat di dunia siber. Cara untuk mengetahui bahwa itu FB palsu adalah dengan mengecek FB-nya, lihat pertemananya kalau sedikit perlu dicurigai, cek postinggannya kalau sedikit juga perlu dicurigai, belum ada up date apa-apa di status, bahkan tidak pernah menulis status, bisa dipastikan ini adalha FB yang palsu. Hacker tadi membuat FB lalu memindahkan foto-foto dari FB yang asli. Bagi orang yang tidak teliti bisa langsung percaya bahwa itu FB asli. Di sinilah pentingnya literasi media.

Salah seorang ibu peserta FGD menyampaikan bahwa ia pernah dikirim inbox massage yang isinya "mbak aku lagi di tempat jauh, pulsa nggak ada. Tolong pulsa diisikan 100 ribu". Peserta FGD lainnya ada yang menyampaikan bahwa temannya dapat inbox dari dosennya di Jerman. "Kirimi saya pulsa nanti saya ganti deh". Dosen gadungan ini menyampaikan kalau dia sedang di Indonesia, sedang tidak bawa ATM banking. Akhirnya dikirimi pulsa. Setelah itu barulah dicek melalui FB-nya ternyata hal tersebut adalah penipuan.

Peserta FGD ibu Laila memiliki pengalaman pernah mendapat telpon dari seseorang yang mengatakan bahwa anaknya kecelakaan. Di belakang sang penelpon ada suara-suara yang ramai. Ibu Lalila menelepon anaknya tersebut, tetapi tidak diangkat-angkat. Semakin menguatkan kalau berita tersebut benar. Namun akhirnya diketahui bahwa berita tersebut bohong.

Pambudi memberikan solusi untuk kasus penipuan kecelakaan tersebut semakin menguatkan untuk memilah dan memilih dalam media. Perlu adanya diskrit di lingkungan sosial. Sesama ibu-ibu yang melek media perlu saling berkomunikasi, berjejaring untuk bertukar informasi. Kita perlu menciptakan keamanan sosial kita sendiri. Misalnya seperti kasus di atas tidak bisa mengontak anak kita, kita bisa mengontak temannya. Harus ada keterbukaan 
di dalam keluarga. Perlu mengetahui siapa saja teman-teman anak kita, nomor telponnya, tempat tinggalnya. Ini tidak melanggar privasi anak, tetapi untuk keamanan bersama. Pelaku kejahatan biasanya mengetahui identitas kita melalui FB.

Hal lain adalah tentang menghadapi anak yang sudah akrab dengan handphone dan internet. Ibu Muryati (peserta FGD) menyampaikan "pengalaman saya terhadap cucu, yakni pada saat cucu saya diberi tahu oleh orang tuanya bahwa tidak boleh membuka aplikasi tertentu di HP Karena dia masih TK. Biasanya kalau dia sudah bosan bermain HP orang tuanya akan bermain dengan simbah putrinya (FGD tgl 20 April 2017). Ibu Elizabet menyatakan " Terkadang kita juga perlu mengontrol HP anak. Misalnya, Saya minta tolong anak untuk mengontrol apa yang dilakukan oleh cucu. Cucu saya hanya boleh pegang HP pada hari Sabtu-Minggu. Misalnya cucu saya yang sekolah di IT (Islam Terpadu). Efek melarang memakai HP lebih baik. Interaksi dengan teman-temannya menjadi semakin baik. Itu membuat teman-temannya datang ke rumah untuk bermain bersama. Sekarang falsafah Jawa sudah terbukti kebenarannya, misalnya kebo nusu gude. Jadi anak sekarang lebih pintar daripada orang tuanya. Malah orang tua yang berguru kepada anak" (FGD tgl 20 April 2017).

Ibu Dwi Haryani mengatakan "Saya membiasakan pada anak untuk disiplin. Yakni dengan membiasakan anak untuk mengontrol waktunya sendiri. Tetapi saya juga tidak protektif dengan anak. Karena anak zaman sekarang tidak bisa lepas dari gadget. Misalnya anak saya yang masih SMA malah disuruh oleh gurunya untuk membawa HP untuk mencari materi pelajaran" (FGD tgl 20 April 2017)

Wening (Psikolog) memberikan masukan mengenai permasalahan yang dihadapi ibuibu rumah tangga terkait penggunaan gadget. Menurutnya tantangan untuk menegakkan peraturan di rumah adalah komitmen. Kalau tidak diterapkan, maka akan mudah dilanggar. Untuk melakukan itu semua, dibutuhkan pendekatan yang lama dan khusus untuk membangun kepercayaan.

Setelah peneliti melakukan pemetaan, sosialisasi, dan pelatihan litersai media, selanjutnyapenelitimemantauperkembanganibuibu rumah tangga dalam mengimplementasikan literasi media di lingkungan mereka. Pada kesempatan acara Dasa Wisma dan PKK, ibuibu yang menjadi agen-agen literasi media ini mensosialisasikan pendidikan literasi media kepada ibu-ibu yang lainnya. Di lingkungan keluarga mereka pun melakukan pendidikan literasi media. Dengan demikian pendidikan dan sosialisasi literasi media digital ini dilakukan secara berantai, baik formal maupun informal.

Peneliti melakukan pemantauan di Dusun-Dusun Kelompok Kerja (Pokja) empat desa terdiri dari 11 (sebelas) dusun perwakilan. Salah satu agen sosialisasi media adalah ibu Totok. Secara fasih ibu Totok memberikan pengarahan dan masukan kepada ibu-ibu anggota pokja empat ini. Berikut petikan muatan pengarahan yang disampaikan ibu Totok:

"Ibu-Ibu perlu membangun komitmen rumah tangga untuk memilih dan memilah informasi media. Abaikan informasi yang tidak berguna, seperti hoax misalnya mendapatkan Rp 390jt karena tanggal lahir dan sebagainya. Dampak positif dari media digital adalah dapat berjualan on line, mempunyai banyak teman. Dampak negatif ada cyber crime, tetapi bisa mendetek tentang seseorang yang akan memeras misalnya meminta pulsa. Ada informasi laten atau terselubung. Karena kami sudah tua kurang mengecek anak cucu yang mengakses internet ternyata ada cara untuk melacaknya. Kesepakatan seisi rumah perlu dilakukan seperti harus ada pendampingan. Perlu diinformasikan bahwa berita yang sudah diposting tidak bisa ditarik kembali. Pulsa saja bisa dibohongi ditelpon sebentar langsung pulsa tersedot. Ada juga yang membohongi dengan menelepon anak sedang di rumah sakit kemudian minta transfer uang, dan sebagainya...". 
Sementara dari pemerintah dalam hal ini adalah Dinas Pendidikan, Pemuda dan Olah Raga DIY, Ibu Isti Tri Asih menyampaikan bahwa teknologi komunikasi Dispora Yogyakarta menggalakkan Generasi Digital 'Immigrants Generation Digital Natives', dengan melakukan beberapa aspek; meningkatkan pengetahuan, meningkatkan ketrampilan, dan membangun koneksi. Kebijakan-kebijakan terkait literasi digital adalah sebagai berikut :

1. Literasi digital bagi peserta didik di Balai Teknologi Pendidikan, ada layanan baik untuk pendidikan formal maupun nonformal. Beberapa kegiatan yang dilakukan diantaranya; pelosok

a. kunjungan ke sekolah-sekolah

b. sosialisasi dunia digital

c. bagaimana memanfaatkan dunia digital dengan bijak

2. Bimbingan teknis dan Pelatihan. Program ini ditujukan bagi pendidik dan peserta didik untuk memanfaatkan TIK dalam pendidikan.

a) Mobile Learning Services. Program literasi digital ini ditujukan bagi lembaga atau sekolah atau komunitas di daerah pinggiran. Pada tahun 2016 ada 100 lokasi di pelosok daerah DIY. Program meningkatkan kualitas pendidikan di sekolah pinggiran melalui TIK.

b) Pengembangan aplikasi mobile

c) Pengembangan Yogyabelajar melalui situs www.jogjabelajar.org merupakan virtual classroom

d) Program ICT EQEP : ICT utilization for education quality enhancement programme untuk 500 sekolah terdiri dari 300 SD dan 200 SMP, 500 lab komputer, serta mengadakan pelatihan dan pendampingan.

Berbagai upaya telah dilakukan baik dari pemerintah maupun dari kalangan akademisi untuk mengentaskan buta media khususnya buta digital media. Salah satu kalangan yang turut andil dalam pengentasan buta media digital ini adalah bapak Nu'man Lutfie, pendiri literos.org. Ia menyampaikan ada tiga upaya literasi media; pertama mendorong masuknya konten literasi media digital dalam kurikulum pra sekolah, SD, SMP, SMA, Universitas, dan pelatihanpelatihan formal Aparatur Sipil Negara (ASN). Kedua, mendorong penyebaran pengetahuan dan etika digital secara masif dan luas dalam format populer dan menarik. Ketiga, mendukung eksistensi dan mendorong lahirnya komunitas, dan relawan.

Nu'man mengkritisi cara pemerintah menghadapi kasus-kasus berita digital dengan memblokir. Padahal menurutnya itu kurang tepat, karena web yang diblokir akan muncul kembali web baru dengan versi yang lainatau dengan nama lain. Menurutnya :

"Netizen sebenarnya bisa report. Ada yang sifatnya urgent; tidak menutup konten-konten yang berbahaya seperti konten Youtube; ada orang yang mau bunuh diri diunggah di youtube, berita ini cepat menyebar tetapi pemerintah telat memutusnya. Kita tidak mungkin menutup youtube atau google, karena penggunanya sangat banyak, tetapi kalau tidak dijaga, maka kedaulatan negara kita tidak terjaga" (Disampaikan tgl 12 Sepetember 2017).

Pandangan senada dari sudut psikologis dipaparkan oleh Dyna Herlina (Pakar Litersi Media Digital). Ia memaparkan fakta fakta baru yakni :

1. Digital native is a myth; Anak-anak membutuhka bimbingan dan pelatihan untuk menggunakan media digital lebih produktif

2. Screen time is not relevant; jika anak atau orang dewasa terobsesi dengan media sosial / gawai / game, maka ia harus dihentikan. Lebih penting memperhatikan bagaimana ia 
berinteraksi dengan gawai dan game serta untuk apa.

3. Variasi pengalaman digital sama pentingnya dengan pengalaman di dunia nyata, karena pekerjaa-pekerjaan baru akan muncul melibatkan media digital

4. Kecanduan internet disebabkan kesepian yang berkepanjangan

5. Penyiksaan dan kekerasan seksual yang dialami oleh anak-anak yang memiliki potensi resiko diabaikan secara fisik dan emosi.

Dyna memberikan solusi bagaimana menggunakan media digital untuk kesejahteraan masyarakat. Pendidikan formal perlu berubah secara mendasar untuk menjawab tantangan perubahan informasi, penguasaan pengetahuan dan kebutuhan belajar sepanjang hayat dari seluruh elemen masyarakat. Orang tua disarankan menggunakan metode pembelajaran kolaboratif yang juga dapat diaplikasikan dalam pendidikan formal.

\section{Pembahasan}

Literasi media digital di era informasi yang tidak bisa lagi dibendung ini perlu mendapatkan perhatian serius dari berbagai kalangan. Baik dari pemerintah, Akademisi (Universitas atau Perguruan Tinggi), Sekolahsekolah (Pra-sekolah, SD, SMP,SMA), NGO, maupun keluarga dalam masyarakat. Kontenkonten yang meresahkan seperti hoax, penipuan, kekerasan, seksualitas, pornografi semua ada pada media digital. Keluarga perlu memiliki konsep dalam menerapkan literasi media. Ada kebijakan dan aturan yang tegas dalam keluarga. Keluarga sebagai benteng pertama bagi anak sebelum ia memasuki dunia luar. Ibu merupakan pilar rumah tangga. Pilar yang kokoh akan menghasilkan rumah tangga yang tangguh. Dengan demikian dibutuhkan ibu-ibu rumah tangga yang tangguh pula. Pendidikan literasi media tidak hanya ditujukan ke lembagalembaga pendidikan saja, tetapi diperlukan juga pada elemen-elemen masyarakat lainnya secara menyeluruh.

Penelitian ini menyasar pada ibu-ibu rumah tangga di Banguntapan Bantul dan Gondomanan Yogyakarta. FGD untuk memetakan kemampuan ibu-ibu dalam memilih dan memilah konten media sudah dilakukan. Setelah itu diberikan pelatihan literasi media serta sosialisasi. Hasilnya ibu-ibu rumah tangga tersebut menjadi mengerti betapa pentingnya pendidikan literasi media bagi keluarga mereka. Mereka tidak ingin putra-putri mereka bahkan cucu mereka sebagai generasi penerus bangsa ini menjadi rusak karena dampak media digital yang semakin mengerikan.

Kehadiran media digital membawa kelebihan dan kelemahan. Adapun Kelebihan media on line adalah sebagai berikut :

1. kecepatan: internet menjanjikan kecepatan realtime, supercepat. Transaksi bisa berjalan lancar dan cepat

2. Jangkauan : menjangkau seluruh penjuru dunia bisa membuat bukan apa-apa menjadi sesuatu yang sangat terkenal bukan apaapa menjadi sesuatu yang sangat terknal (populer)

3. Kekayaan isi : konten media hampir tak terbatas, serba ada, serba terkait (hyper link)

4. Multi guna : komunikasi apapun bisa menggunakan media baru: pendidikan, keluarga, bisnis, kegiatan keagamaan, olah raga dll

5. Kemudahan : relatif tidak memerlukan keahlian khusus untuk mengakses dan memproduksi pesan di media baru.

Kelemahan media digital (media baru) :

1. Content risks : Pornografi, kekerasan, isu rasial, isu radikalisme, muatan kebencian, dan lain-lain.

2. Contact risks: cyber bullying, pelecehan seksual, ancaman,penyerangan privacy, identitas palsu

3. Conduct risks : penipuan, manipulasi informasi, hak cipta, perjudian, download ilegal, hacking, dan lain-lain. http://www. lpminstitut.com/2017/04/literasi-media- 
untuk-apa.html diunduh tgl 08-06-2017

Byron Reeves dan Clifford Nass mengemukakan The Media Equation Theory, mereka menyatakan bahwa media diibaratkan manusia. Teori ini memperhatikan bahwa media juga bisa diajak berbicara. Media bisa menjadi lawan bicara individu seperti dalam komunikasi interpersonal yang melibatkan dua orang dalam situasi face to face adalah benar adanya. Ibu-ibu rumah tangga di Banguntapan Bantul mengakui bahwa mereka sangat tergantung dengan media digital. Disamping berfungsi positif seperti bisa digunakan sebagai alat bertukar informasi, sebagai media untuk mengundang acara-acara tertentu, untuk berjualan secara online, mendapatkan informasi-informasi, juga berdampak negatif.

Banyak penipuan dilakukan melalui media on line, berita hoax, pornografi, dan sebagainya seperti yang telah diutarakan di atas. Dari segi waktupun banyak tersita hanya untuk melihat aplikasi dan konten-konten yang menarik di media digital. Anak-anak dari ibuibu rumah tangga ini bahkan mengonsumsi informasi melalui gadget lebih banyak daripada ibu-ibu rumah tangga tersebut. Ibu-ibu rumah tangga tersebut secara aktif, suka rela dan senang hati menjadi agen-agen sosialiasi literasi media di lingkungan dimana mereka berada. Setiap ada kesempatan acara program rutin seperti Pokja, acara dasa wisma, PKK, mereka menyempatkan diri untuk memberikan pengarahan sosialiasi literasi media. Pendampingan terhadap anak menjadi sangat penting. Oleh karena ibu-ibu rumah tangga sebagai agen-agen literasi media di Banguntapan Bantul telah berjalan dan terlihat hasilnya, bahkan secara gethuk tular (word of mouth) sosialisasi ini dijalankan. Desa Babadan Banguntapan Bantul layak menjadi Pilot Project Desa Melek media digital.

Gambaran model literasi media digital bagi ibu-ibu rumah tangga yang sudah diterapkan sebagaimana penjelasan di atas adalah sebagai berikut:

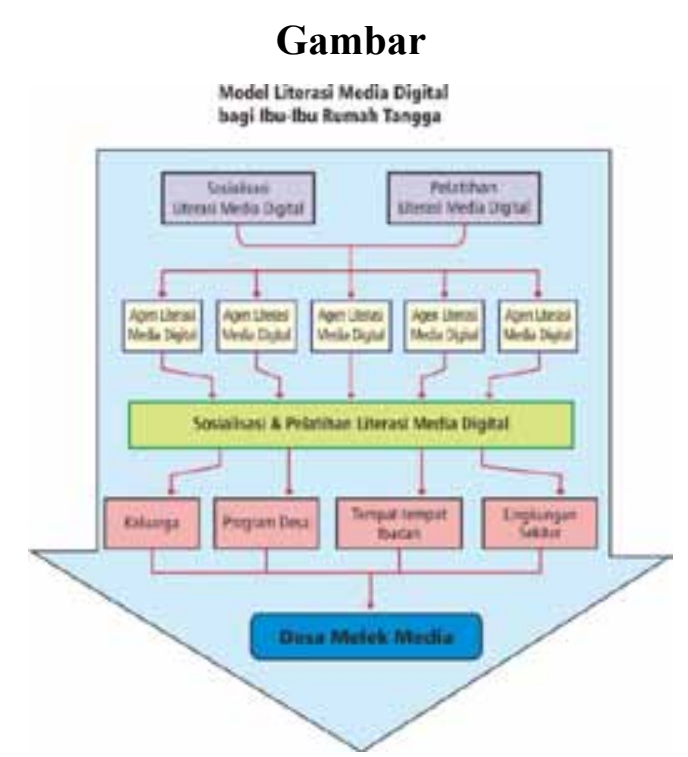

Model di atas diawali dari kegiatan gerakan literasi media yang dimotori oleh kalangan akademisi, para peneliti literasi media digital, pemerintah (Kominfo atau Dispora), NGO, pemerhati masalah literasi media digital. Elemenelemen tersebut bisa secara bersama-sama atau secara mandiri melakukan sosialisasi dan pelatihan atau pendidikan literasi media digital. Sosialisasi dan pelatihan ditujukan kepada ibuibu rumah tangga yang telah dipilih memiliki smartphone/HP, mampu mengoperasionalkannya secara sederhana, aktiv di lingkungan sekitar seperti pengurus Dasa Wisma, PKK, Pengajian, bahkan ibu-ibu pekerja. Ibu-ibu ini diarahkan untuk menjadi agen-agen sosialisasi media dlingkungan mereka berada. Ibu-ibu rumah tangga tersebut dalam penggunaan media digital tidak hanya sampai pada level menggunakan (usage), tetapu juga sampai pada level memahami (understansing) dan level memproduksi (creat). Selanjutnya ibu-ibu ini menyosialisasikan literasi media digital di lingkungan mereka berada. Utamanya sosialisasi ditujukan kepada keluarga mereka masing-masing, kemudian pada setiap kesempatan pertemuan aktivitas atau program desa (pertemuan dasa wisama, pokja, PKK), di tempat-tempat ibadah (Masjid melalui pengajian), dan di lingkungan di mana ibu-ibu ini berada. Agen-agen yang bergerak ini tidak berhenti sampai disitu, secara berkesinambungan 
akan melahirkan agen-agen baru yang secara kontinyu menyosialisasikan literasi media digital. Kedepannya desa dimana literasi media ini digalakkan akan menjadi percontohan desa melek media. Desa-desa lain bisa mengikuti untuk melakukan gerakan litarasi media dengan mengundang agen-agen dari desa percontohan tersebut. Begitu seterusnya secara berantai yang pada akhirnya menciptakan masyarakat Indonesia melek akan media digital.

\section{Simpulan}

Media digital marak diperbincangkan akhir-akhir ini. Khalayak bisa secara bebas mengonsumsi dan memproduksi konten-konten yang demikian luas dalam media digital. Sepintas tidak ada ada masalah karena teknologi semakin berkembang menuntut masyarakat untuk terus bisa mengikutinya agar tidak ketinggalan kemajuan. Namun dibalik kemajuan teknologi ini membawa konsekuensi yang luar biasa besar. Perubahan peradaban pun terjadi dengan diciptakannya media baru ini. Kelebihannya seperti yang sudah diutarakan di atas diantaranya dari segi kecepatan, sangat cepat; dari segi jangkauan menjangkau seluruh dunia; kekayaan isi tak diragukan berbagai konten ada; multiguna komunikasi apapun bisa menggunakan media digital; : relatif tidak memerlukan keahlian khusus untuk mengakses dan memproduksi pesan di media baru Namun yang lebih berat adalah konsekuansi negatif; Pornografi, kekerasan, isu rasial, isu radikalisme, muatan kebencian, cyber bullying, pelecehan seksual, ancaman, penyerangan privacy, identitas palsu, penipuan, manipulasi informasi, hak cipta, perjudian, download ilegal, hacking, dan lain-lain. Dampak negatif inilah yang perlu menjadi perhatian besar bagi berbagai kalangan. Penelitian ini menjaring pendapat dari berbagai kalangan seperti ibuibu rumah tangga (sebagai subyek penelitian), Psikolog, pakar digital media, akademisi, NGO, dan pemerintah. Semua memiliki kaca mata yang sama terhadap literasi media digital. Semua pihak memiliki andil yang besar untuk mewujudkan masyarakat yang cerdas dalam mengonsumsi media khususnya media digital. Ibu-ibu rumah tangga dipilih dalam penelitian ini karena ibu-ibu rumah tangga merupakan pilar rumah tangga dalam keluarga. Apabila pilar ini kuat, maka rumah tangga tersebut akan kokoh. Benteng pertama bagi generasi penerus adalah keluarga, untuk itu ibu-ibu rumah tangga perlu dibekali pendidikan literasi media. Ibuibu rumah tangga di Banguntapan Bantul yang telah dipilih berhasil menjadi agen-agen sosialisasi pendidikan literasi media digital di lingkungannya. Mereka secara aktif dan suka rela memberikan pengarahan sosiliasi literasi media di lingkungan mereka melalui programprogram tetap di organisasi dasa wisma, PKK, Pokja dan sebagainya. Dengan demikian desa Banguntapan Bantul layak dicanangkan sebagai desa pilot project literasi media digital.

\section{Saran}

Saran yang bisa diberikan :

1. Perlu ada sosialisasi dan pelatihan media digital khususnya bagi kalangan ibu-ibu rumah tangga secara berkesinabungan.

2. Selain itu, masyarakat pun hendaknya mulai membangun self sensor awareness,

3. Perlu adanya sinergi antara pemerintah (Kemenkominfo), Komisi Penyiaran Indonesia (KPI), Non Goverment Organisation, dan para pakar media baik dari Perguruna Tinggi maupun praktisi media, untuk duduk bersama membuat program sosialisa literasi media digital bagi ibu-ibu rumah tangga.

\section{Daftar Pustaka}

\section{Buku}

Baran, Stanley and Dennis K Davis. 2000. Mass communication theory. Wadsworth: Canada

Berger, Charles R., and Chafee, StevenH., 2010, The Handbook of Comunication Science, Sage Publication, Newbury Park London, New Delhi

Denzin, Norman K dan Lincoln, Yvonna. 1994. Handbook of Qualitative Research. 
London : Sage Publications

Guntarto, B. 2007. Pendidikan Media - Buku Pegangan Untuk Guru Sekolah Dasar. Jakarta: Yayasan Pengembangan Media Anak dan UNICEF.

James, Potter W., 2005, Media Literacy, third edition. Sage Publication: New Delhi.

Littlejohn, Stephen W. 1999. Theories of Human Communication. sixth edition.

California : Wadsworth Publishing Company.

Martin, Allan. 2009. Digital Literacy fot the Third Age: Sustaining Identity in an Uncertain McLuhan, Marshall, 2003, Understanding Media, Routledge, London and Newyork.

Moleong, Lexy J. 2006, Metode Penelitian Kualitratif. PT Remaja Rosdakarya:Bandung

Neuman, W Lawrence. 2000. Social Research Methods : Qualitative and Quantitative Approaches. fourth edition. Boston : Allyn and Bacon.

Sasangka dan darmanto. 2010, Ketika Ibu Rumah Tangga Membaca televisi. Tifa Yogyakarta

Sendjaya, Sasa Djuarsa, Dkk, 1993, Pengantar Komunkasi, Universitas Terbuka, Jakarta Soemandoyo, Priyo. ND. Wacana Gender dan Layar Televisi: Studi Perempuan dalam Pemberitaan Televisi. Ford Foundation dan LP3Y: Yogyakarta.

Sutopo, HB. 2002. Metode Penelitian Kualitatif. Surakarta: UNS PRESS.

Wiratmojo, 2010, Ketika Ibu Rumah Tangga Membaca televisi. Tifa :Yogyakarta

\section{Jurnal}

Guntarto, B. 2001. Internet and the New Media: Challenges for Indonesian Children. Dalam Media Asia, 28 (4):195-203.

\section{Sumber lain:}

http://www.antaranews.com diakses tgl 04-04 2016

http://www.bantulkab.go.id/kecamatan/
Banguntapan.html diakses tgl 10-02-2015

https://icca.co.id/social-media-overdosis/ diakses tgl 10-06-2017

http://www.lpminstitut.com/2017/04/literasimedia-untuk-apa.html diunduh tgl 08-06-2017

https://www.google.co.id/search?q=data+pengg una+internet + indonesia $+2017 \&$ source diakses tgl 17-08-2017

http://www.lpminstitut.com/2017/04/literasimedia-untuk-apa.html diunduh tgl 08-06-2017

http://www.mediaawareness.ca/english/ corporate/media_kit/digital_literacy_paper_pdf/ digitalliteracypaper_part1.pdf unduh 08-062017.

https://indonesia-medialiteracy.net/tag/literasimedia-baru/tgl unduh 08-06-2017. 